\title{
Diversity of Microorganisms Associated to She Camels' Subclinical and Clinical Mas titis in South Sinai, Egypt
}

\author{
*Marwa El Sayed Abo Hashem, **Sara Mohamed Ibrahim, \\ ***Azza Said Gouda and ****Enany, Mohamed El Sayed \\ *Bacteriology, Immunology and Mycology Department, Faculty of \\ Veterinary Medicine, Suez Canal University. (corresponding author) \\ drvet42@yahoo.com (marwashassan@vet.suez.edu.eg \\ ** Animal Production of South Sinai Research Station \\ Sarakort2020@gmail.com \\ *** Animal Health Department of Desert Research Center, Cairo \\ Azzagooda500@yahoo.com \\ ****Bacteriology, Immunology and Mycology Department, Faculty \\ of Veterinary Medicine, Suez Canal University.enanyeg@yahoo.com
}

\begin{abstract}
The current study aimed to detect microbial causes of she camel's subclinical and clinical mastitis and antibiotic sensitivity test for some bacterial isolates. A total of 196 milk samples were collected from mastitic and apparent healthy she camels, milk samples of apparent healthy she camels were examined by California mastitis test for detection of subclinical mastitis. All samples were cultivated on different media for detection of bacteria and fungi causing mastitis. $S$. aureus and Acholeplasma were subjected to antibiotic sensitivity test to detect antibiotic of choice. Out of 40 apparently healthy she camels, subclinical mastitis was detected in 19 (47.5\%). Out of 196 she camels milk samples, 40 samples were positive for bacterial isolation (20.4\%). E. coli and Staphylococcus epidermidis were the most predominant isolated bacteria from apparently healthy she camel milk samples while Pseudomonas aeruginosa, Staphylococcus epidermidis and Streptococcus agalactia from mastitic she camel's milk samples. This is the first record for isolation of Acholeplasma laidlawii in South Sinai where 4 Acholeplasma laidlawii isolates were isolated from mastitic and apparent healthy she camel milk samples. Aspergillus niger was the most predominant fungi followed by Candida albicans. The most predominant mixed bacterial infection in apparent healthy she camels was Proteus vulgaris and Staphylococcus epidermidis while from mastitic she camels was Pseudomonas aeruginosa and Klebsiella pneumoniae. S.
\end{abstract}


aureus was sensitive to gentamycin, streptomycin, erythromycin, tetracycline, ciprofloxacin and nitrofurantion. Acholeplasma laidlawii was sensitive to gentamycin. From the obtained results, it was concluded that she camels' mastitis was caused by several bacteria and fungi either by single or mixed infection.

Key words : Mastitis, California mastitis test, Antibiotic sensitivity test.

\section{Introduction}

Mastitis is defined as an inflammation of the parenchymal tissue of the mammary gland. It is characterized by physical and chemical changes in the milk and pathological changes in glandular tissue of the udder which include swelling, heat, pain, and edema of mammary gland. The most important changes in the milk include discoloration, presence of clots and presence of a large number of Leukocytes (Hadef et al., 2018). Mastitis is a relatively infrequent disease in camels compared with cattle, but the incidence of mastitis may increase in dairy camels due to hand milking and teat malformation (Al-Tofaily and Al-Rodhan 2011). Many infective agents have been implicated as causes of mastitis in camel, however, bacterial infections are considered the primary cause of mastitis (Seifu and Bekele, 2010) either in the form of pure or mixed infection (Abdella and Mohammed, 2014). Various studies had been conducted worldwide on the isolation and identification of bacteria causing camel mastitis and their effect on quantity and quality of milk. Staphylococcus aureus, Staphylococcus epidermidis, Micrococcus spp., Pasteurella haemolytica and Escherichia coli were the main causes of she-camel mastitis $(\boldsymbol{A l}$ Juboori et al., 2013). Also, Streptococcus agalactiae was considered as one of the most important causes of mastitis in camel (Fischer et al., 2013). Yeasts caused mastitis as Candida spp., Cryptococcus spp., Rhodoturulla spp., Sacharomyces spp. and Trichosporon spp. Meanwhile, molds as Aspergillus spp., Penicillium spp., Alternaria spp., Aerobasidium spp., Geotrichum spp. and Pichia spp. (Ahmad and Gholib, 2016). Subclinical mastitis is costly disease due to no clinical sings and if not detected at time may progress to clinical mastitis and it may be caused by fungus such as Aspergillus spp., Trichosporon spp. and Candida spp. (Radostits et al., 2010). The 
most common causative bacteria of subclinical mastitis were coagulase positive and coagulase negative Staphylococcus, Coliform bacteria (Eman et al., 2012). California mastitis test (CMT) was used to detect the subclinical mastitis of she camel compared to bacterial isolation, it was found that CMT is fast and effective, but less sensitive in diagnosis of subclinical mastitis than bacterial isolation (Hayder et al., 2018). Hence, this study aimed to detect microbial causes of clinical and subclinical mastitis in she camels.

\section{Materials and methods}

\section{Sampling}

One hundred ninety-six raw camel's milk samples were collected from 67 she camels (diseased and apparently healthy) from different farms in Ras Sudr of south Sinai (South Sinai research station of the desert research Center and different farms of Bedouins). Samples were collected under aseptic conditions according to National Mastitis Council (1999).

2. California mastitis test (CMT):

Forty milk samples were collected from apparently healthy and tested by CMT to detect the prevalence of subclinical mastitis. CMT was done according to Schalm et al. (1971).
3. Bacteriological examination of milk samples:

A loopful of each raw milk sample was inoculated into nutrient broth (Oxoid) and selenite cystine broth (Oxoid) then incubation at $37^{\circ} \mathrm{C}$ for 24 hours then take loopful from nutrient broth culture and cultivate on nutrient agar (Oxoid), MacConkey's agar (Oxoid), brain heart infusion agar (Oxoid), mannitol salt agar (Oxoid) and litmus milk media (Oxoid) for isolation of different bacteria. A loopful from selenite cystine broth culture is cultivated on S.S agar for isolation of Salmonella and other Enterococcus species then incubate at $37^{\circ} \mathrm{C}$ for 24 hours, then morphological and biochemical identification was done according to Quinn et al. (1994). Isolation of Acholeplasma was done according to Hazelton et al. (2018). Acholeplasma isolation from milk samples was done by using Mycoplasma agar (Oxoid CM0401) and broth (Oxoid CM0403) supplemented with Mycoplasma selective supplement G (Oxoid SR0059)

\section{Isolation and identification of yeast and mold}

Milk samples were cultivated on Sabouraud Dextrose Agar (Oxoid), Examine plates for fungal colonies exhibiting typical color and morphology. Yeasts will grow as creamy to 
white colonies. Molds will grow as filamentous colonies of various colors.

\section{Antimicrobial} susceptibility testing of isolated bacteria

$S$. aureus as an important bacteria causing mastitis and globally showing high level of antimicrobial resistance was tested against 9 antibacterial agents (penicillin $10 \mu \mathrm{g}$, ampicillin $10 \mu \mathrm{g}$, vancomycin 30 $\mu \mathrm{g}, \quad$ gentamycin $10 \mu \mathrm{g}$, streptomycin $\quad 100 \quad \mu g$, erythromycin $15 \mu \mathrm{g}$, tetracycline $30 \mu \mathrm{g}$, ciprofloxacin $5 \mu \mathrm{g}$ and nitrofurantion $300 \mu \mathrm{g})$ and Acholeplasma laidlawii was tested against 6 antibacterial agents (tobramycin $10 \mu \mathrm{g}$, spirumycin $100 \mu \mathrm{g}$, enrofloxacin $5 \mu \mathrm{g}$, erythromycin $10 \mu \mathrm{g}$, amikacin $20 \mu \mathrm{g}$ and gentamycin $200 \mu \mathrm{g})$. Antibiogram was performed using disk diffusion method as described by Ewing (1986) and Cruickshank (1975). The results were interpreted according to guidelines of Clinical and Laboratory Standards Institute (2015).

\section{Results}

1. Prevalence of subclinical she camel mastitis using CMT: Out of 40 apparent healthy she camel's subclinical mastitis was detected in 19 she camels by CMT with a percentage of $47.5 \%$.
2. Bacteriological

examination of she camel's milk samples:

Out of 196 she camel's milk samples (134 sample from apparently healthy she camels, 62 from mastitic she camel's) from South Sinai Research Station and Bedouin farms, 40 samples (8 samples from apparently healthy she camels, 32 from mastitic she camel's) were positive for bacterial isolation with a percentage of $20.4 \%(4.08 \%$ from apparently healthy she camels, $16.32 \%$ from mastitic she camels).

3. Prevalence of Gramnegative bacteria in apparently healthy and clinical mas titic she camels

Concerning bacterial isolates obtained from apparently healthy she camel's milk samples, E. coli was the most predominant isolated bacteria with a prevalence of $35.4 \%$ followed by Pseudomonas aeruginosa, Klebsiella pneumonia, Proteus vulgaris, Shigella flexneri, Enterobacter aerogenes, and Serratia marcescens with a prevalence of $20.8 \%, 20.8 \%, 10.4 \%, 8.3 \%$, $2.1 \%$ and $2.1 \%$ respectively. On the other hand, the most predominant bacteria isolated from mastitic she camel's milk samples were Pseudomonas aeruginosa and $E$. coli with a prevalence of $28.4 \%$ and $27 \%$ followed by Klebsiella 
pneumonia, Shigella flexneri, Enterobacter aerogenes, Yersinia enterococci, Proteus valgaris, Serratia marcescens and Salmonella typhimurium with a prevalence of $16.2 \%$, $14.9 \%, 6.8 \%, 2.7 \%, 1.4 \%, 1.4 \%$ and $1.4 \%$ respectively.

4. Pre valence of Gram positive bacteria in apparently healthy and clinical mastitic she camels Concerning bacterial isolates obtained from apparently healthy she camel's milk samples, Staphylococcus epidermidis was the most predominant isolated bacteria with a prevalance of $70.7 \%$ followed by Streptococcus agalactiae, Bacillus cereus and Enterococcus faecalis with a prevalence of $22 \%, 4.9 \%$ and $2.4 \%$ respectively. On the other hand, the most predominant bacteria isolated from mastitic she camel's milk samples were Staphylococcus epidermidis and Streptococcus agalactiae with a prevalence of $33.3 \%$ for each followed by Bacillus cereus, Staphylococcus aureus and Enterococcus faecalis with a prevalence of $18.2 \%, 9.1 \%$ and $6.1 \%$ respectively.

\section{Prevalence of Acholeplasma}

Bacteriological examination of 196 raw camel's milk samples of apparently healthy and mastitic she camels to detect the prevalence of Acholeplasma, the results showed that, 4 isolates were characterized by fried egg appearance Acholeplasma laidlawii was detected with a prevalence of $2.04 \%$ (4/196).

6. Prevalence of fungi in apparently healthy and clinical mastitic she camels

Aspergillus niger (A. niger) was the most predominant mold isolated from apparently healthy she camel's milk samples with a prevalence of $93.3 \%$. Also, Candida albicans ( $C$. albicans) yeast was isolated from apparent healthy she camel's milk samples with a prevalence of $6.7 \%$. Concerning mastitic she camel's milk samples, the most predominant isolated mold was A. niger with a prevalence of $64.9 \%$ followed by C. albicans yeast with prevalence of $29.7 \%$. Also, Aspregillus flavus (A. flavus) and Aspergillus fumigatus (A. fumigatus) molds were isolated by $2.7 \%$ for each.

7. Prevalence of mixed bacterial infection:

Mixed bacterial infection was detected in apparently healthy and mastitic she camels where the most predominant mixed bacterial infection in case of apparently healthy was Proteus valgaris and Staphylococcus epidermidis with a prevalence of $36.4 \%$ while, the most predominant mixed bacterial infection in case mastitic she camels was Pseudomonas aeruginosa and Klebsiella pneumoniae with a prevalence of $25 \%$. 
8. Antibiotic sensitivity test of S. aureus and Acholeplasma. Antibiotic sensitivity test by disk diffusion method revealed that $S$. aureus was resistant to penicillin, ampicillin and vancomycin while was sensitive to gentamycin, streptomycin, erythromycin, tetracycline, ciprofloxacin and nitrofurantion. Acholeplasma laidlawii was resistant to tobramycin, spirumycin, enrofloxacin, erythromycin, amikacin while, sensitive to gentamycin.

\section{Discussion}

Mastitis is a global problem as it adversely affects animal health, economics of milk production and quality of milk. It affecting every country, including developed ones and causes huge financial losses (Sharma et al., 2007). In this study, the prevalence of subclinical mastitis using California mastitis test was $47.5 \%$ and these results were higher than those obtained by Memon et al. (2019) and Mogeh et al. (2019) where the prevalence rate of subclinical mastitis was $22.75 \%$ and $25.8 \%$ respectively. The high prevalence of subclinical mastitis may be attributed to poor hygienic condition of milking area and tick infestations act as rick factor for incidence of subclinical mastitis. The most Gram-negative pathogen recovered from apparent healthy and mastitic she camels was $E$. coli with a prevalence of $30.3 \%$, these results were similar to those obtained by Yam et al. (2015) but were higher than those reported by Hadef et al. (2018) and Mogeh et al. (2019) who detected $E$ coli by $10.72 \%$ and $21 \%$ respectively. E. coli is one of the most common causes of mastitis (Abdella and Mohammed 2014). The high prevalence of $E$. coli may be attributed to coliform environmental mastitis with poor hygienic condition in milking area. Pseudomonas aeruginosa was isolated in a prevalence of $25.4 \%$ and this was higher than those obtained by Al-Juboori et al. (2013) and Mogeh et al. (2019) where the prevalence of Pseudomonas aeruginosa isolates was $1.66 \%$ and $6.25 \%$ respectively. The study revealed that the most common Grampositive isolates from mastitic and apparent healthy she camels was Staphylococcus epidermidis with a prevalence of $54.1 \%$, these results were agreed with those obtained by Sundhan and Sharma (2010) and Memon et al. (2019) who stated that, Staphylococcus epidermidis is the one of the most predominant isolates in camel herds also caused mastitis. The prevalence of Staphylococcus aureus was $4.05 \%$, these results were similar to those obtained by Hussein et 
al. (2013) and Hanna and Abeer (2015) where the prevalence of S. aureus was $4.2 \%$ and $3.33 \%$ respectively. Meanwhile, Mogeh et al. (2019) found that the prevalence of $S$. aureus was $24.2 \%$. The prevalence of Streptococcus agalactiae isolates was $27 \%$, these results were higher than those obtained by Memon et al. (2019) where the prevalence of Streptococcus isolates was $13.2 \%$. Meanwhile, Saleh and Faye (2011) detected high prevalence of Streptococcus isolates (42.9\%). In the current study, Acholeplasma laidlawii was isolated from mastitic she camel in South Sinai and this is the first record for isolation of Acholeplasma laidlawii in this area, where Acholeplasma laidlawii was isolated in a percentage of $2.04 \%$. Mederos et al. (2014) isolated Acholeplasma laidlawii and Acholeplasma oculi from camel species. Meanwhile, Ebtesam (2016) and Al-Farha et al. (2017) isolated Acholeplasma laidlawii from clinical and subclinical mastitis cases of cattle. Al-Farha et al. (2017) isolated A. laidlawii in a percentage of $10.8 \%$. Ebtesam (2016) isolated Acholeplasma spp. from clinical and subclinical mastitis milk samples of dairy cows in percentage of $10.3 \%$ and $5.6 \%$ respectively. The lower detection of Acholeplasma laidlawii as a cause of mastitis in camels than cattles may be attributed to species of animals and genetic factors.

She camel mastitis may be caused by fungus such as Aspergillus spp. and Candida spp. (Radostits et al., 2010). In the present study, the prevalence of fungi isolated from apparent healthy and mastitic she camel was $20.6 \%$ and the most predominant fungi was Aspergillus niger $(73.1 \%)$ followed by Candida albicans (23.07\%).

Meanwhile, Aspergillus flavus and Aspergillus fumigatus present with low percentage $1.9 \%$ for each one. Hanaa et al. (2011) detected prevalence of Candida albicans, Aspergillus fumigatus and Aspergillus niger by $10.5 \%$, $9 \%$ and $2 \%$ respectively. Mosaad et al. (2011) found that the prevalence of Candida albicans, Aspergillus niger and Aspergillus fumigatus was $10 \%$, $2.5 \%$ and $2.5 \%$ respectively. $\boldsymbol{A l}$ Dughaym and Fadlelmula (2015) detected that the prevalence of Aspergillus fumigatus, Candida albicans and Aspergillus niger was $10 \%$, $7.5 \%$ and $5.7 \%$ respectively. The high prevalence of fungi in the current data may be attributed to the udder infestation by ticks which act as a predisposing factor for mastitis. Mixed bacterial infection from mastitic and apparent healthy she camels was $13.8 \%$, these results were 
lower than those obtained by Hadef et al. (2018) where mixed bacterial infection was $54.9 \%$.

Concerning, antibiotic sensitivity test of $S$. aureus the obtained results detected that it was sensitive to gentamycin, streptomycin, erythromycin, tetracycline, ciprofloxacin and nitrofurantion. Meanwhile, it was resistant to penicillin, ampicillin and vancomycin. Mogeh et al. (2019) and Memon et al. (2019) reported that $S$. aureus was sensitive to gentamycin but Ali et al. (2019) reported that $S$. aureus was resistant to gentamycin. On the other hand, the study revealed that $S$. aureus was sensitive to streptomycin and this agreed with Al-Tofaily and Rodhan (2011) and Badria et al. (2016) who reported that $S$. aureus was sensitive to streptomycin, however Ali et al. (2019) found that $S$. aureus was resistant to streptomycin. In this work, $S$. aureus was sensitive to erythromycin and this was similar to those obtained by Badria et al. (2016) but disagreed with those obtained by Al-Tofaily and Rodhan (2011) where they reported that $S$. aureus was resistant to erythromycin. From the current study, S. aureus was sensitive to tetracycline this agreed with Ismail (2015). On the other hand, Mogeh et al. (2019) found that $S$. aureus was resistant to tetracycline. The present work stated that $S$. aureus was sensitive to ciprofloxacin and this agreed with Yam et al. (2015) but Ali et al. (2019) found that $S$. aureus was resistant to ciprofloxacin. Also, in the present study $S$. aureus was sensitive to nitrofurantion and this agreed with Tuteja et al. (2003). S. aureus was resistant to ampicillin, penicillin and vancomycin, and these results were similar to those obtained by Ali et al. (2019) but Subramaniyan et al. (2016) reported that $S$. aureus was sensitive to ampicillin.

The study detected that Acholeplasma laidlawii was sensitive to gentamycin, meanwhile it was resistant to tobramycin, spirumycin, enrofloxacin, erythromycin and amikacin and these results were disagreed with those obtained by Tomar et al. (2017) who reported that Acholeplasma laidlawii was sensitive to amikacin, enrofloxacin and spirumycin.

\section{References}

Abdella, M. E. and Mohammed, G. E. (2014): Clinical Study on Camel Mastitis (Camelus dromedarius) at Butana Region, Sudan. Journal of Agricultural and Veterinary Sciences (SJAVS) 15, 82-94. Ahmad, R. Z. and Gholib, D. (2016): Mycotic mastitis caused 
by Candida spp. and Trichosporons spp. on dairy farm in Bogor, Bandung, and Jakarta. Journal Veteriner.17, 119-125.

Al-Dughaym, A. M. and Fadlelmula, A. (2015): Prevalence, etiology and its seasonal prevalence of clinical and subclinical camel mastitis in Saudi Arabia. British Journal of Applied Science \& Technology. 9, 441-449.

\section{Al-Farha,}

Hemmatzadeh, F., Khazandi, M., Hoare, A. and Petrovski, K. (2017): Evaluation of effects of Mycoplasma mastitis on milk composition in dairy cattle from South Australia. BMC Vet. Res. $13,1-8$.

Ali, M., Avais, M., Ljaz, M., Chaudhary, M., Hussain, R., Aqib, A.L., Khan, N.U., Sohail, M.L., Khan, M., Khan, M.A., Ahmad, M., Hasni, M. S., Qaiser, L., Rashid,G., Haq,L. and Khan,L (2019): Epidemiology of subclinical mastitis in dromedary camels (camelus dromedaries) of two distinct agro-ecological zones of Pakistan . Pakistan J. zool. 51, 527-532.

Al-Juboori, A.A. Kamat, N. K., and Sindhu, J. I. (2013): Prevalence of some mastitis causes in dromedary camels in Abu Dhabi, United Arab Emirates. Iraqi J. vet. Sci. 27, 914.
Al-Tofaily, Y. I. and AlRodhan, M. A. (2011): Study on clinical mastitis (Bacteriological) in she-camels (Camelus dromedarius) in some areas of middle Euphrates in Iraq. AL-Qadisiya Journal of Vet. Med. Sci. 10, 66-76.

Aqib, A. I., Ijaz, M., Durrani, A. Z., Anjum, A. A., Hussain, R., Sana, S., Farooqi, S. H., Hussain, K. and Ahmad, S. S. (2017): Prevalence and antibiogram of Staphylococcus aureus, a Camel Mastitogen from Pakistan., Pakistan J. Zool. 49, 861-867.

Badria, A. M., Somaya, A. F., Gaidan, O. K. and Mohamed T. E. (2016): Isolation of bacteria from sub-clinical cases in mastitic she-camel (Camelus Dromedaries) and their sensitivity to some antibiotics. Alexandria Journal of Veterinary Sciences. 51, 54-60.

Clinical and Laboratory Standards Institute (2015): Performance standards for antimicrobial susceptibility testing; twenty-fifth informational supplement. Vol. 35. Clinical and Laboratory Standards Institute, Wayne, PA, USA.

Cruickshank, R. (1975): Medical Microbiology. In: The Practice of Medical Microbiology. Vol. 2. Churchill Livingstone, Edinburgh.

Ebtesam, S. O. (2016): Relationship between mastitis 
and Mycoplasma bovis. Degree of Master of Science in Agricultural Sciences (Agricultural Microbiology). Department of Agricultural Microbiology. Faculty of Agriculture. Cairo University. Egypt.

Eman, M. F., Raghib, R. W., Saudi, A. M. and EL-Essawy, H. A. (2012): Chemical and microbiological assessment of raw camel's milk with special reference to subclinical mastitis monitoring in Egypt. Assiut Vet. Med. J. 58, 1-15.

Ewing, W. H. (1986): Edwards and Ewing's identification of Enterobacteriaceae, 4th Edition. Elsevier Science Publishing Co., Inc., New York.

Fischer, A., Liljander, A., Kaspar, H., Muriuki, C., Fuxelius, H. H., Bongcam Rudloff, E., Villiers, E. P., Huber, C. A., Frey, J., Daube nberger, C., Bis hop, R., Younan, M. and Jores, J. (2013): Camel Streptococcus agalactiae populations are associated with specific disease complexes and acquired the tetracycline resistance gene tet $\mathrm{M}$ via a Tn916-like element. Vet. Res. 44, 1-10.

Hadef, L., Aggad, H., and Hamad, B. (2018): Bacterial causative agents associated with subclinical mastitic in dromedary she-camels in Southeastern Algeria, Jordan
Journal of Biological Sciences. 11, $209-214$.

Hanaa, A. E., Saad, M. A. and Rabab, M. K. (2011): Histopathological and microbiological studies on the teat affections in she-camel. Global Veterinaria. 7, 129-137. Hayder, M. A., Abdulameer, A. H. and Asaad, C. A. (2018); Diagnostic study of she camel subclinical mastitis in Al-Hyadia District-Al-Najaf province, Advances in Animal and Veterinary sciences, 6, 278-280.

Hazelton, M. S., Sheehy, P. A., Bos ward, K. L., Parker, A. M., Morton, J. M., Dwyer, C. J., Niven, P. G. and House, J. K. (2018): Short communication: shedding of prevalence of Mycoplasma bovis in bovine clinical mastitis milk in Egypt 08 Mycoplasma bovis and antibody responses in cows recently diagnosed with clinical infection. J. Dairy Sci. 101, 584589.

Huss ein, A., Haftu, B., Hunde, A. and Tesfaye, A. (2013): Prevalence of camel (Camelus dromedaries) mastitis in Jijiga Town, Ethiopia: Afr. J. Agric. Res. 8, 3113-3120.

Ismail, M. A. (2015): Epidemiological study on camel mastitis in North Kordofan State, Sudan degree of master of Tropical animal health, (M.T.A.H), Department of preventive medicine and veterinary public health, Faculty 
of veterinary medicine,

University of Khartoum.

Mederos, L. E., Poveda, J. B., Poveda, C.G., Vega-Orellana, O. M., Gutiérrez, C., Corbera, J. A. and Ramírez, A. S. (2014): Mycoplasma detection and isolation from one-humped camels (Camelus dromedarius). Trop. Anim. Health Prod. 46,1317-1320.

Memon, M. R., Baloch, J. A., Memon, M. I., Leghari, R. A., Kunbhar, H. K., Kore jo, N. A., Sethar, A., Soomro, J., Soomro, S. A., Kalhoro, D. H., Kachiwal, A. B., Kanwal, B., Jamel, T. and Shaikh J. A. (2019): A study on prevalence of bacteriological mastitis in dromedary camels (Camelus dromedarius) and its antibiogram profile, Sindh Univ. Res. Jour. 51, 237-242.

Mogeh, A. O., Teklu, A. and Ogleh, M. D. (2019): The prevalence of mastitis and its associated risk factors in lactating dromedary camels in and around hargesa, Somaliland. International journal of Scientific and Engineering Research. 10, 201-211.

Mosaad, A., El- kirdasy, A., El Tamalli, M., El-sherif, M., And El-Bagory, A. M. (2011): Biochemical studies on the virulence factors of fungi associated with she-camel milk, J. Basic. Appl. Chem. 1, 15-20.

National Mastitis Council (N.M.C) (1999): Laboratory hand book on bovine mastitis. National mastitis council, Madison, WI.

Quinn, P. J., Carter, M. E., Markey, B. and Carter, G. R. (1994): Clinical Veterinary Microbiology,

Wolfe Publishing, London (1994) ISBN 0-7234-1711-3.

Radostits, O. M., Gay, C. C., Blood, D. C. and Hinchcliff, K.W. (2010): Veterinary Medicine: A Textbook of the Diseases of Cattle, camel, Sheep, Pigs, Goats and Horses. 9th Edition, ISBN-13: 9780702026041.

Saleh, S. K. and Faye, B. (2011): Detection of subclinical mastitis in dromedary camels (Camelus dromedaries) using somatic cell counts, California mastitis test and udder pathogen. Emir. J. Food Agric. 23, 48-58.

Schalm, O. W., Carrol, E. and Jain, N. C. (1971); Bovine mastitis. 1st ed. Lea and Febiger, Philadelphia, USA.

Seifu, E. and Bekele, T. (2010): Prevalence and etiology of mastitis in traditionally managed camels (Camelus dromedarius) in selected pastoral areas in Eastern Ethiopia. Ethiop. Vet. J.14, 103-113.

Sharma, N., Maiti, S. K. and Sharma, K. K. (2007): Prevalence, etiology and antibiogram of microorganisms associated with sub clinical mastitis in buffaloes in Durg, 
Chhattisgarh State (India). Int. J. Dairy Sci. 2, 145-151.

Subramaniyan, A., Dheeba, B., Hameed, S. A. and Palanis amy, S. (2016): Plasmid profiling with respect to identification of multidrug resistance in Staphylococcus aureus isolated from dairy products. Scholars Research Library. 8, 214-225.

Sundhan, N. A. and Sharma, N. (2010): Mastitis: An important production disease of dairy animals. Sarva Manav Vikash Samiti, Gurgaon, India. 72-88

Tomar, P., Singh, Y., Mahajan, N. and Jindal, N. (2017): In vitro antimicrobial sensitivity of avain Mycoplasma isolated from broiler chicken flocks affected with respiratory infections. Int. J. Pure. App. Biosci. 5, 1329 - 1334.

Tuteja, F. C., Dixit, S. K., Ghorui, S. K., Deen, A. and Sahani, M. S. (2003): Prevalence, characterization and antibiotic sensitivity of intra mammary infections in camel. Journal of Camel Practice and Research. 10, 69-77.

Yam, B. A., Khomeiri, M. and Sadeghi, A. (2015): Isolation and identification of yeasts and lactic acid bacteria from local traditional fermented camel milk, chal. J. Food Process Techno. 6, 1-6.

الأسباب الميكروبية لالتهاب الضرع تحت الإكلينيكي و الإكلينيكي للإبل في جنوب سيناء ،

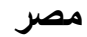

مروة السيد أبو هاثم* ، سارة محمد ابراهيخ*** ، عزة سعيد جوده**** ، محمد السيد

$$
\begin{aligned}
& \text { * عنانى }
\end{aligned}
$$

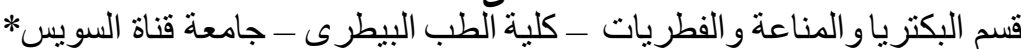

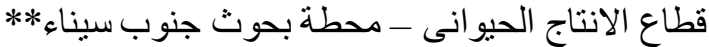

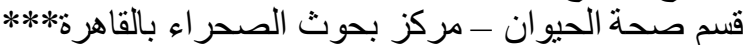

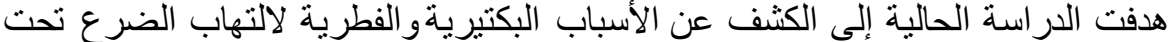

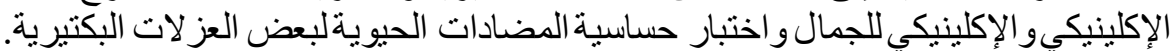

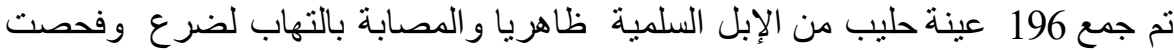

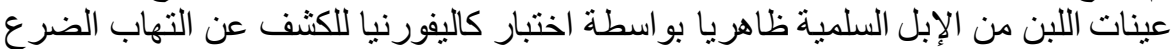

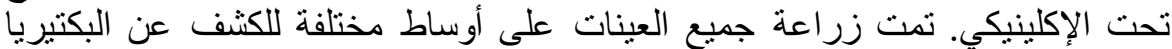

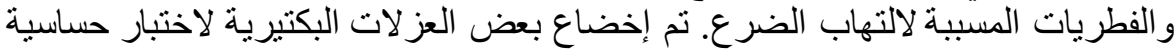

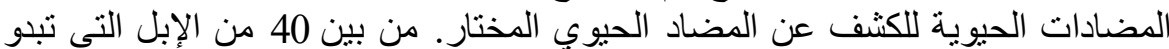

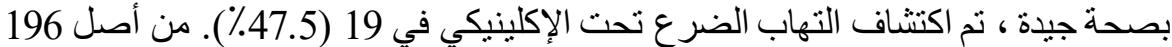

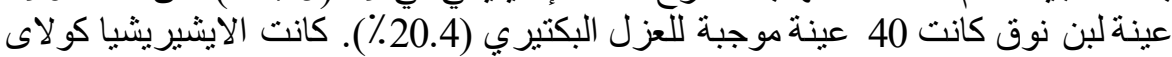

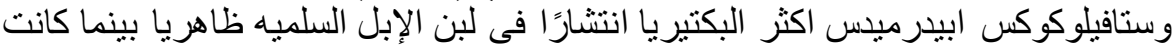

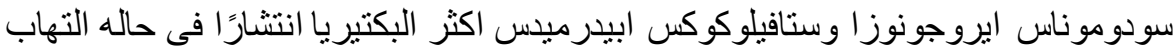

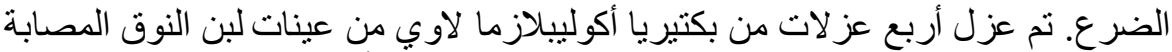
بالتهاب الضرع و السليمة ظاهريا. كانت الاسبيرجيلس نيجر أكثر الفطريات النيات انتشارًا تليها 
كانديدا البيكانز. كانت العدوى البكنيرية المختلطة الأكثر انتشارًا في الإبل السليمة ظاهريا

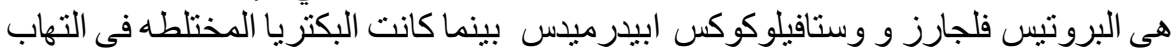

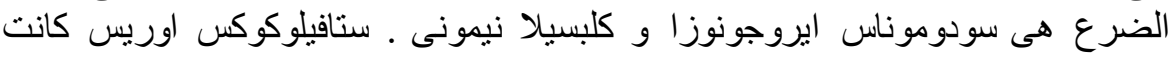

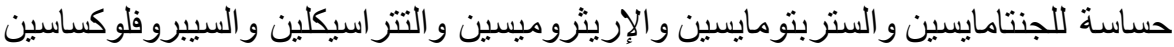

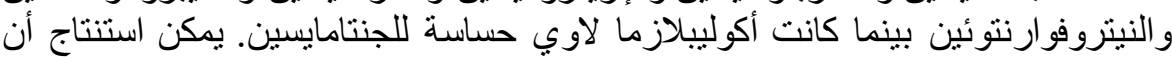

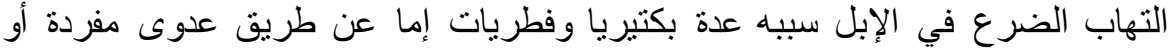
مختلطة. 